\title{
MOOCs: Adoption, Perceived Benefits and Hurdles among the Engineering Faculties of Karnataka
}

\author{
Vysakh, C. ${ }^{1 *}$ and Rajendra Babu, $\mathrm{H}^{2}$
}

${ }^{1}$ Research Scholar, DOSR in Library \& Information Science, Tumkur University, Karnataka, India

${ }^{2}$ Assistant Professor, DOSR in Library \& Information Science, Tumkur University, Karnataka, India

*Corresponding author: chingathvysakh@gmail.com

Received: 21 Oct., 2020

Revised: 29 Nov., 2020

Accepted: 15 Dec., 2020

\begin{abstract}
The present study aims to explore the adoption and benefits of MOOCs among the faculties of selected engineering colleges in Karnataka. A descriptive research design was deployed for the study. Two hundred copies of the structured questionnaire were distributed to collect data from the faculties of four reputed engineering colleges affiliated with Visvesvaraya Technological University (VTU), Belagavi. It was found that only $67.62 \%$ of faculties were aware and hooked on the MOOCs platforms. $38.30 \%$ of the faculties made use of MOOCs for gaining knowledge, $25.53 \%$ for conducting research and $22.34 \%$ to publish contents. The study found the positive impact of MOOCs on the knowledge and carrier prospects of faculties. Lack of time and interest were the major hurdles cited by the participants in adopting MOOCs. The study provides valuable insights into the faculties of Indian higher education institutions to make use of MOOCs technology for a better experience and output for teaching and learning and also to overcome the challenges in adoption.
\end{abstract}

Keywords: MOOCs, Massive Open Online Course, Digital e-learning, Online learning, Engineering College, Karnataka

Massive Open Online Courses or MOOCs are the new form of online learning which changed how both teacher and students learn, work and collaborate (Brahimi \& Sarirete, 2015; Margaryan, et al. 2015). The term was first used in 2008 for an online open course called

How to cite this article: Vysakh, C. and Rajendra Babu, H. (2020). MOOCs: Adoption, Perceived Benefits and Hurdles among the Engineering Faculties of Karnataka. TechnoLearn: An International Journal of Educational Technology, 10(1\&2): 57-69. 
Connectivism and Connective Knowledge (CCK08) at the University of Manitoba, Canada. Later, a good number of MOOCs platforms and courses came into existence and received wide reception from media, educational professionals and vendors all over the globe (Yuan \& Stephen, 2018). In the year 2018 alone, the number of MOOCs users crossed 58 million globally (Natalie, 2018) and the expert marked MOOCs as a Tsunami in the ocean of education which has challenged the way traditional pedagogy has been carried out in academic institutions (Arya, 2017). The main attraction of MOOCs is that it is open, free and online (Kay et al. 2013). Concerning the status of MOOCs in India, studies show that the country is lagging in adoption \& use and yet to shine as compared to other countries (Chakravarty \& Kaur, 2016). University Grant Commission (UGC) in India has notified in 2017 that MOOC courses are to be offered through SWAYAM (Study Webs of Active -Learning for Young Aspiring Minds) (Singh \& Chauhan, 2017). In this study, we attempted to know the extent of adoption of MOOCs by the selected engineering colleges and their respective faculties of the state of Karnataka.

\section{What is MOOC?}

According to Chakravarty \& Kaur (2016) "A massive open online course (MOOC) is a free Web-based distance learning program that is designed for the participation of a large number of students irrespective of the geographical barriers".

* Barnes (2013) defined MOOC as a "specific type of online course which is characterized by no formal entrance requirements, free participation, and online availability and designed for thousands".

\begin{tabular}{|c|c|c|c|}
\hline swavain & & About Swayam | All Ce & National Coordinators I Local Chapters \\
\hline & & Search Catalog... & SIGN-IN / REGISTER \\
\hline & $\begin{array}{l}\text { Basic Building Blocks of } \\
\text { Microwave Engineering... } \\
\text { Prof. Amitabha Bhattacharya } \\
\text { IIT Kharagpur } \\
\text { NPTEL } \\
8 \text { Weeks (Starts: } 27-01-2020 \text { ) } \\
\text { Exam Date: } 29 \text { Mar, 2020 } \\
\text { Enrollment Ends: } 3 \text { Feb, } 2020\end{array}$ & $\begin{array}{l}\text { Basic Principles and } \\
\text { Calculations in } \\
\text { Chemical... } \\
\text { Prof. Subrata Kumar Majumdar } \\
\text { IIT Guwahati } \\
\text { NPTEL. } \\
12 \text { Weeks (Starts: 27-01-2020) } \\
\text { Exam Date: } 26 \text { Apr, 2020 } \\
\text { Enrollment Ends: } 3 \text { Feb, } 2020\end{array}$ & $\begin{array}{l}\text { Bioengineering: An } \\
\text { Interface with Biology } \\
\text { and... } \\
\text { Prof. Sanjeeva Srivastava } \\
\text { IIT Bombay } \\
\text { NPTEL } \\
8 \text { Weeks (Starts: } 27-01-2020 \text { ) } \\
\text { Exam Date: } 29 \text { Mar, 2020 } \\
\text { Enrollment Ends: } 3 \text { Feb, } 2020\end{array}$ \\
\hline & (iv) $(-2=2$ & & T \\
\hline https://swayam.gov.in/nd1_noc20_ee35/preview & Chemical Reaction & Contral Fnainaorina & Effective Engineering \\
\hline
\end{tabular}

Picture 1: Engineering Courses available in Swayam 
MOOCs: Adoption, Perceived Benefits and Hurdles among the Engineering Faculties of Karnataka $Y$ P

As mentioned above, the entire process of MOOC takes place on web platforms. The aspirants can register for courses online being offered by major MOOCs providers. Coursera, EdX, XuetangX, Udacity million and Future Learn are the top five world wide providers of MOOCs (Dhawal, 2018). The process involves selecting the platform, creating an account, deciding the way to learn (Audited, Certified and Specialization), enrolling and completing the course.

\section{Purpose and Significance of the study}

MOOCs are the digital way of handling the teaching and learning process by offering stimuli for developing the concepts of e-learning by the use of Web 2.0 and open educational resources. It can be used before, meanwhile or after the completion of a degree course or even integrated with the current course module (Pradeep Kumar, 2018). The main purpose of this study is to analyse the use and perceived benefits of MOOCs among the engineering faculties of Karnataka state. Many previous studies reported that the adoption and use of MOOCs in India are not up to the mark (Chakravarty \& Kaur, 2016; Singh \& Chauhan, 2017; Shaikh, 2017). Since engineering faculties are tech-savvy and early adopters of technology (Schrum et al. 2008; Jackson, 2011), to what extent they are familiar with these kinds of online classes is to be assessed on which no previous studies traced out. Furthermore, how the adoption has affected their profession and what are all the major challenges they are facing to integrate MOOCs to be explored. The findings of the study certainly help the educators to adopt and integrate MOOCs as well as to overcome the challenges in adoption.

\section{Objectives of the study}

As the time and situation calls for the academic institutions to make use of various blends of ICT, the investigation aims to know, to what extent the engineering colleges faculty members in Karnataka make use of it for teaching and learning using MOOCs. The major aims of the study are as follows:

1. To gauge the awareness and use ofMOOCs among the faculty members of selected engineering colleges in Karnataka.

2. To find the purposes of the use of MOOCsamong the faculties.

3. To assess the benefits of using MOOCs among the faculties.

4. To understand the major hurdles in adopting MOOCs among the faculties.

\section{Scope and Methodology of the Study}

This study was conducted to know the use and benefits of MOOCs among the engineering faculties of the selected colleges in Karnataka state. A descriptive survey having a structured questionnaire was distributed among faculties of four major engineering colleges viz. Kalpataru 
Institute of Technology (KIT), Shridevi Institute of Engineering \& Technology (SIET), Sri Siddhartha Institute of Technology (SSIT) and Siddaganga Institute of Technology (SIT).A total of 200 questionnaires were distributed and 139 returned (found apt for analysis).The questionnaire included specific questions like the use of MOOCs (various platforms) and the benefits of MOOCs. The data collected further subjected to analysis using descriptive statistics including frequency and percentage which are presented in tables and graphs. The major findings of the study are discussed in the upcoming section.

\section{Previous notable studies}

Khalil \& Sultana (2017)reported that Pakistani teachers who were working in public and private universities were not well aware of the potentials of MOOCs when 50 teachers were surveyed. Furthermore, private teachers tend to show more interest in using MOOCs than teachers working in public universities. A significant difference also reported among IT and Non-IT inclined students in participating in MOOCs (Muhammad, Mustapha B, \& Haruna, 2016) MOOC is globally becoming a key instrument in digitally mediated learning and teaching, due to its ability to provide interactive user forums to support community interactions among participants and instructors. Despite its global acceptance, countries in sub-Saharan Africa suffer some drawbacks within the context of awareness and adoption. Kano state is one of the cities in Sub-Saharan Africa with high population where MOOCs participation is significantly needed. Therefore, the rationale of this study is to appraise the level of awareness, perceived benefits and challenges of MOOCs adoption among University students of Kano State, Nigeria. The study was conducted in form of a survey using structured questionnaire administered to three hundred (300. A similar kind of study conducted among 216 primary and secondary school teachers in Greek delineated that majority of the participants were ready to adopt MOOCs for professional development but found a low level of awareness about various MOOCs platforms (Bakogianni Eleni, Tsitouridou, \& Kyridis, 2020). While Soyemi \& Babalola (2018) from Nigeria reported that more than half of the surveyed librarians were well aware of MOOCs, but the enrollment was meagre. Adding to this, the majority of the LIS educators in India were aware of MOOCs and the adoption have helped them in professional and personal learning. Lack of time was the major challenge faced by educators in the adoption of MOOCs (Sawant, 2016). The enrolled students from America opined that they enrolled for MOOCs because of two educational challenges viz. online social network engagement reasons or peer-to-peer networking.

In the Indian context, adoption of MOOCs reported to be in its primary stage and there is a need to make the teachers aware and acquaint with these online courses (Singh \& Chauhan, 2017). When Chatterjee \& Asoke (2014) surveyed 500 students from India, it was found that majority of the students $(82 \%)$ were interested in digital mode of learning like MOOCs but only $9 \%$ of them got admitted to any such courses which go in line with the study findings 
MOOCs: Adoption, Perceived Benefits and Hurdles among the Engineering Faculties of Karnataka $Y \mathcal{P}$

of Shaikh (2017). He reported that even teachers are getting enrolled, the number of teachers who successively complete the course was very low and the dropout rate is very high (Nagasampige, Subbaiah, \& Nagasampige, 2020). There are many challenges in adopting MOOCs especially in developing countries (Barriers \& Mooc, 2018) and this study would be investigating the adoption, perceived benefits and obstacles in MOOCs among the engineering faculties of selected colleges in Karnataka.

\section{Data analysis and interpretation}

(Note: Data given in parenthesis can be read as a percentage)

\section{General Information}

Table 1 shows that from 139 respondents surveyed 73.40 per cent were male and the remaining 26.60 per cent were female respondents showing the dominance of male in engineering courses. This finding is corroborated by another previous study conducted by Goel (2007). He reported the less aspiration of female to join engineering degrees as compared to other courses like Science, Arts and humanities. It is also clear that the majority of the respondents $(70.50 \%)$ were ME/ M.Tech graduates followed by $21.60 \% \mathrm{PhD}$ holders. Concerning the institution of working, 46 faculties were from SSIT, 40 from KIT, 29 from SIT and the remaining 24 from SIET. It is also ostensible from the table that most of the respondents $(61.10 \%)$ were assistant professors of which the majority tend to be male(41.71\%). The number of guest faculties accounted for only 2 or $1.40 \%$ and who were female participants.

Table 1: General Information

\begin{tabular}{cccc}
\hline Response & Male & Female & Total (N=139) \\
\hline Gender & $102(73.40)$ & $37(26.60)$ & $139(100.00)$ \\
\hline Qualification & & & \\
\hline ME/ M.Tech & $69(49.60)$ & $29(20.90)$ & $98(70.50)$ \\
MSc & $5(3.60)$ & $2(1.40)$ & $7(5.00)$ \\
MBA & $0(0.00)$ & $1(0.70)$ & $1(0.70)$ \\
M.Phil. & $3(2.20)$ & $0(0.00)$ & $3(2.20)$ \\
PhD & $25(18.00)$ & $5(3.60)$ & $30(21.60)$ \\
\hline Institution & & & \\
\hline K.I.T & $30(21.60)$ & $10(7.20)$ & $240(28.80)$ \\
S.I.E.T & $18(12.90)$ & $6(4.30)$ & $29(20.90)$ \\
S.I.T & $16(11.50)$ & $13(9.40)$ & $46(33.10)$ \\
S.S.I.T & $38(27.30)$ & $8(5.80)$ &
\end{tabular}


Vysakh and Rajendra

\begin{tabular}{cccc}
\hline Occupation & \multicolumn{3}{c}{} \\
\hline Guest Faculty & $0(0.00)$ & $2(1.40)$ & $2(1.40)$ \\
Assistant Professor & $58(41.70)$ & $27(19.40)$ & $85(61.10)$ \\
Associate Professor & $21(15.10)$ & $6(4.30)$ & $27(19.40)$ \\
Professor & $23(16.50)$ & $2(1.40)$ & $25(17.90)$ \\
\hline Total & $\mathbf{1 0 2 ( 7 3 . 4 0 )}$ & $\mathbf{3 7 ( 2 6 . 6 0 )}$ & $\mathbf{1 3 9 ( 1 0 0 . 0 0 )}$ \\
\hline
\end{tabular}

\section{Adoption,period of adoption and Source of information about MOOCs}

Fig. 2 and 3 indicate the adoption and period since the respondents adopted MOOCs. Of the total respondents, 67.62 per cent had adopted and the remaining 32.38 per cent yet to espouse MOOCs. Concerning the period of using MOOCs platforms, $41.40 \%$ were using for 1 year followed by $27.60 \%$ since 1 to 2 years and $13.80 \%$ since 2 to 3 years. $17.0 \%$ of the faculties were using MOOCs for 3-4 years as seen in the figure.

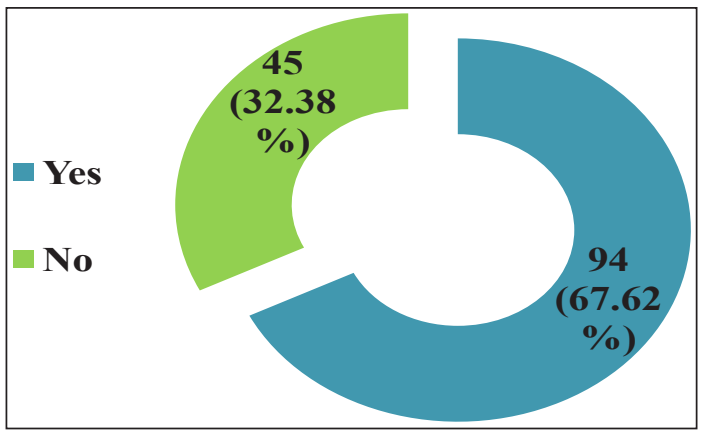

Fig. 2: Adoption of MOOCs

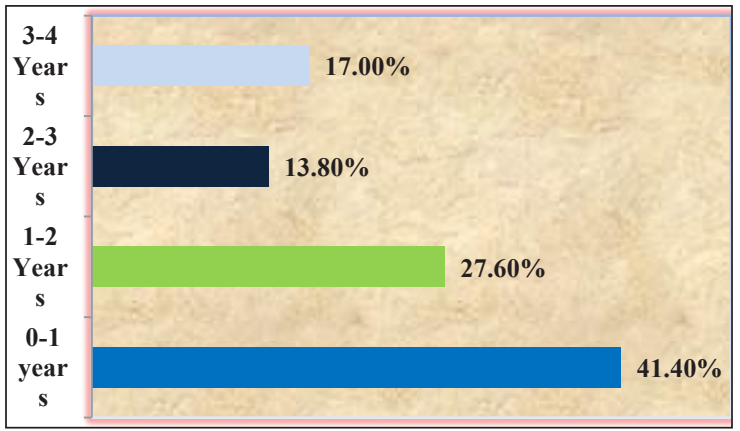

Fig. 3: Period of using MOOC's

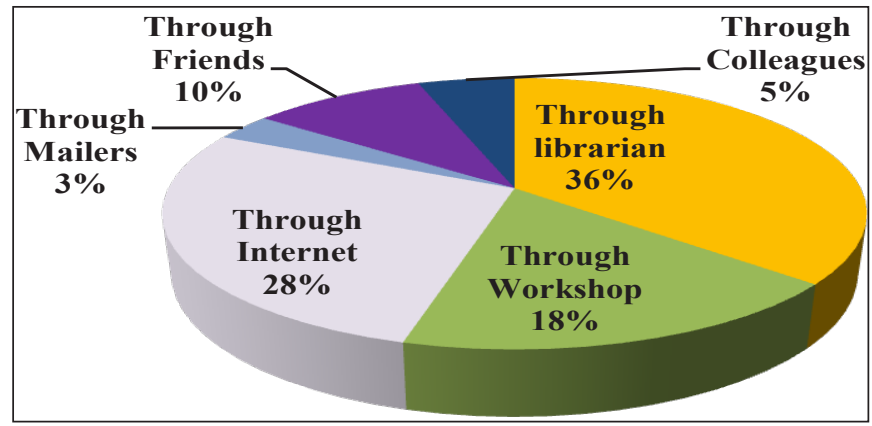

Fig. 4: Source of Information about MOOCs

So it is explicit that even the majority of the participants (94 or $67.62 \%$ ) had been part of the MOOCs, only a few participants hooked for 3 to 4 years and nearly half of them (41.40\%) were recent adopt MOOCs. According to Fig. 4, the Majority of the respondents came to know about 
MOOCs: Adoption, Perceived Benefits and Hurdles among the Engineering Faculties of Karnataka $Y \mathcal{P}$

MOOCs through librarians (36\%) followed by internet sources (28\%) and workshops (18\%) respectively. Only a few respondents got to know through colleagues (5\%) and mailers (3\%).

\section{Familiarity with MOOCs Providers}

When assessed the familiarity about the top eight MOOCs platforms being ranked by Reviews. Com (Brian, 2019) among the faculties, it was crystal clear that the majority of the respondents were highly familiar with all MOOCs platforms. Coursera was cited to be the favourite one as $73.40 \%$ of the participants were highly familiar with the platform followed by Edx and Canvas. net with $64.8 \%$ and $53.1 \%$ respondents respectively. In other previous similar kinds of studies brought that Coursera emerged as a favourite one among the Indian LIS faculties (Sawant, 2016) and the students in Nigeria (Muhammad et al. 2016) MOOC is globally becoming a key instrument in digitally mediated learning and teaching, due to its ability to provide interactive user forums to support community interactions among participants and instructors. Despite its global acceptance, countries in sub-Saharan Africa suffer some drawbacks within the context of awareness and adoption. Kano state is one of the cities in Sub-Saharan Africa with high population where MOOCs participation is significantly needed. Therefore, the rationale of this study is to appraise the level of awareness, perceived benefits and challenges of MOOCs adoption among University students of Kano State, Nigeria. The study was conducted in form of a survey using structured questionnaire administered to three hundred (300. Nearly half of the participants were highly familiar with Future Learn $(48.9 \%)$, Udacity $(46.8 \%)$ and Novoed $(47.8 \%)$. It is also understandable that more than half of the faculties were highly familiar with Udemy $(57.4 \%)$ and Iversity $(61.7 \%)$. It is interesting to see that there were no participants who cited that they never heard about courses like Coursera, Udacity, Udemy and Iversity.

Table 2: Familiarity with MOOCs Providers

\begin{tabular}{lcccccc}
\hline \multicolumn{1}{c}{$\begin{array}{c}\text { MOOC } \\
\text { providers }\end{array}$} & $\begin{array}{c}\text { Highly } \\
\text { Familiar }\end{array}$ & Familiar & $\begin{array}{c}\text { Moderately } \\
\text { Familiar }\end{array}$ & $\begin{array}{c}\text { Not } \\
\text { Familiar }\end{array}$ & $\begin{array}{c}\text { Not at all } \\
\text { heard about } \\
\text { it }\end{array}$ & Total (N=94) \\
\hline Coursera & $69(73.4)$ & $17(18.0)$ & $7(7.4)$ & $1(1.0)$ & $0(0.00)$ & $94(100)$ \\
Edx & $61(64.8)$ & $26(27.6)$ & $2(2.1)$ & $3(3.1)$ & $2(2.1)$ & $94(100)$ \\
Canvas.net & $50(53.1)$ & $31(34.2)$ & $7(7.4)$ & $3(3.1)$ & $3(3.1)$ & $94(100)$ \\
Future learn & $46(48.9)$ & $33(35.1)$ & $11(11.7)$ & $3(3.1)$ & $1(1.0)$ & $94(100)$ \\
Udacity & $44(46.8)$ & $30(31.9)$ & $15(15.9)$ & $5(5.3)$ & $0(0.00)$ & $94(100)$ \\
Novoed & $45(47.8)$ & $33(35.1)$ & $8(8.5)$ & $6(6.3)$ & $2(2.1)$ & $94(100)$ \\
Udemy & $54(57.4)$ & $27(28.7)$ & $8(8.5)$ & $5(5.3)$ & $0(0.00)$ & $94(100)$ \\
Iversity & $58(61.7)$ & $22(23.4)$ & $10(10.6)$ & $4(4.2)$ & $0(0.00)$ & $94(100)$ \\
\hline
\end{tabular}




\section{Purpose of using MOOCs}

Fig. 5 depicts the purpose of the use of MOOCs platforms by the respondents. Of the 94 respondents, 38.30 per cent used it for gaining knowledge while 25.53 per cent for conducting research. 21 participants adopted MOOCs to publish their contents. Only a few respondents $(12.76 \%)$ exchanged ideas through MOOCs platforms. It is to be noted that the use of MOOCs is not up to the mark especially for professional and academic purposes which correlate with the study findings of Khalil \& Sultana (2017). They reported the under use of MOOCs for professional purposes by Pakistani teachers.

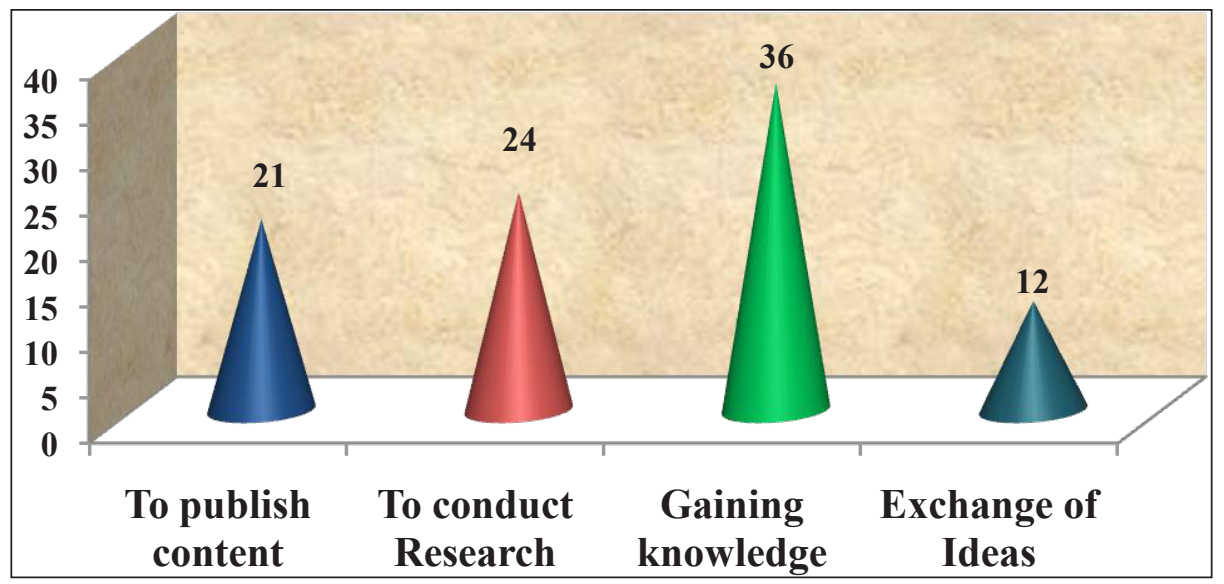

Fig. 5: Purpose of using MOOCs

\section{Benefits of using MOOCs}

Respondents were asked to specify the major benefits that they got by adopting MOOCs and the results are given in Table 3 . As per the table,the majority of the respondents strongly agreed that their career and knowledge level has had a positive impact on the use of MOOCs. Nearly half of the respondents $(45.74 \%)$ cited that they learned different languages because of being part of the classes. MOOCs also provide a platform for scholarly communication among like minded subjects experts which is clear from the table. $40.42 \%$ of the respondents agreed that they could make networks among their peers through MOOCs. $57.44 \%$ of the respondents opined that the use of MOOCs benefitted them to prepare academically.

\section{Hurdles in using MOOCs}

An attempt was also made to find out the major hurdles faced by the respondents while integrating MOOCs and according to Fig. 6, the major hurdle cited by participants was lack 
of time which had been reported in other previous studies from India (Sawant, 2016; Mohan, Upadhyaya, \& Pillai, 2020) MOOCs' adoption and completion rate remain unimpressive, especially among developing countries. Using Extended Unified Theory of Acceptance and Use of Technology (UTAUT2 and Nigeria (Soyemi \& Babalola, 2018). Lack of interest was also cited as a major hurdle by $42.55 \%$ of the participants which supports the findings of Shaikh (2017). He reported that the perception of students teachers pursuing B. Ed. And M. Ed towards MOOCs was negative. $40.42 \%$ of the participants felt the courses are lengthy. The content and design of the MOOCs courses might be another reason which has been cited in another study (Amantha Kumar \& Al-Samarraie, 2019). Only a few participants cited internet problems $(21.27 \%)$ and lack of facilities $(24.46 \%)$ as a major bottleneck. Since most of the engineering faculties are tech-savvy, only a very few participants cited a lack of technical knowledge as a hurdle that barred them to adopt MOOCs.

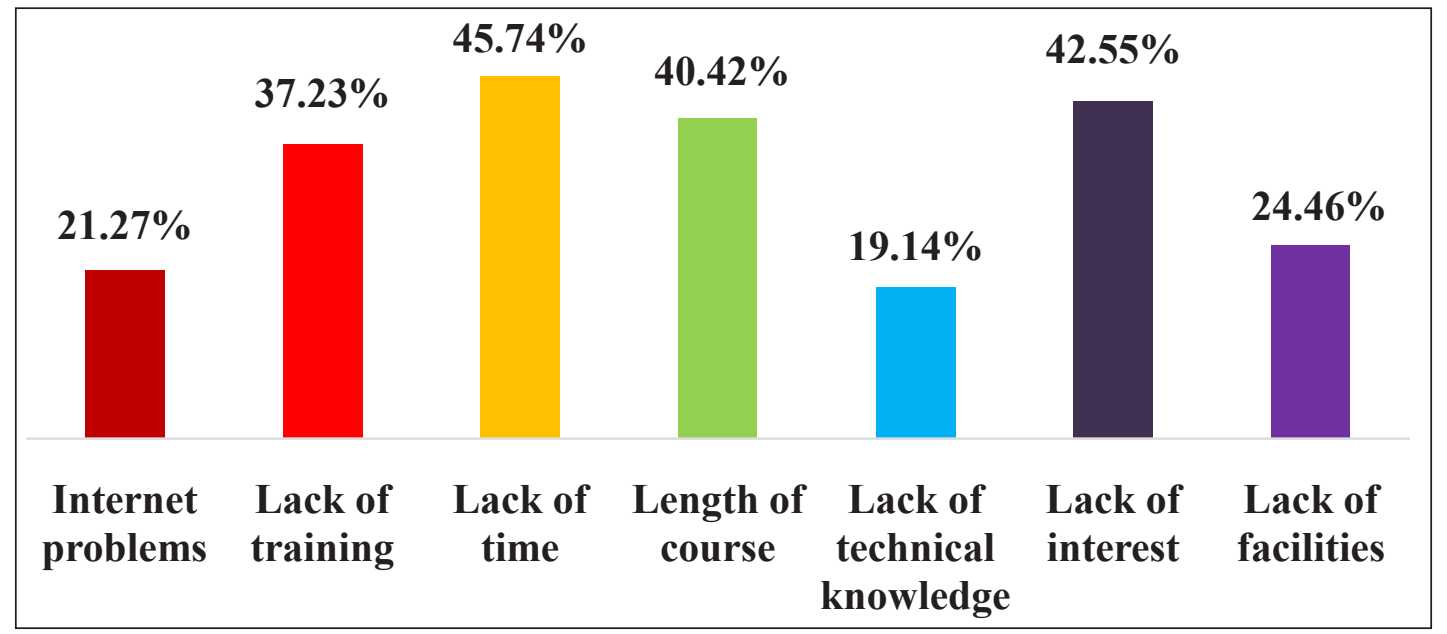

Fig. 6: Hurdles in using MOOCs

Table 3: Benefits of using MOOCs

\begin{tabular}{lcccccc}
\hline Benefits & $\begin{array}{c}\text { Strongly } \\
\text { Agree }\end{array}$ & Agree & Neutral & Disagree & $\begin{array}{c}\text { Strongly } \\
\text { Disagree }\end{array}$ & $\begin{array}{c}\text { Total } \\
(\mathbf{N = 9 4 )}\end{array}$ \\
\hline $\begin{array}{l}\text { MOOCs improved my career } \\
\text { prospects. }\end{array}$ & $49(52.1)$ & $38(40.4)$ & $6(6.3)$ & $1(1.0)$ & $0(0)$ & $94(100)$ \\
$\begin{array}{l}\text { MOOCs helped to update my } \\
\text { knowledge. }\end{array}$ & $55(58.6)$ & $32(34.0)$ & $5(5.3)$ & $1(1.0)$ & $1(1.0)$ & $94(100)$ \\
$\begin{array}{l}\text { MOOCs helped me to learn } \\
\text { different languages }\end{array}$ & $30(31.91)$ & $43(45.74)$ & $10(10.63)$ & $7(7.44)$ & $4(4.25)$ & $94(100)$
\end{tabular}


P

Vysakh and Rajendra

MOOCs helped me to increase my peer network

$\begin{array}{lccccc}28(29.78) & 38(40.42) & 15(15.95) & 8(8.51) & 5(5.31) & 94(100) \\ 42(44.68) & 37(39.36)) & 8(8.51) & 5(5.31) & 2(2.12) & 94(100) \\ 54(57.44) & 33(35.10) & 4(4.25) & 2(2.12) & 1(1.06) & 94(100)\end{array}$

MOOCs helped to improve my

technical knowledge.

MOOCs helped me to prepare

academically for college

\section{Overall satisfaction with the use of MOOCs}

Respondents were requested to express their overall satisfaction with the adoption of MOOCs and the result shows that nearly half of the participants (46.80\%) were moderately satisfied and a good number of participants (32.99\%) were highly satisfied. Only $20.21 \%$ of the participants were not fulfilled with the adoption of MOOCs. It was found from the previous result that most of the respondents are facing a lot of challenges in adopting the MOOCs successfully. So, to make the faculties more participative on MOOCs, steps to be undertaken by the government, institutions, faculties and all other stakeholders.

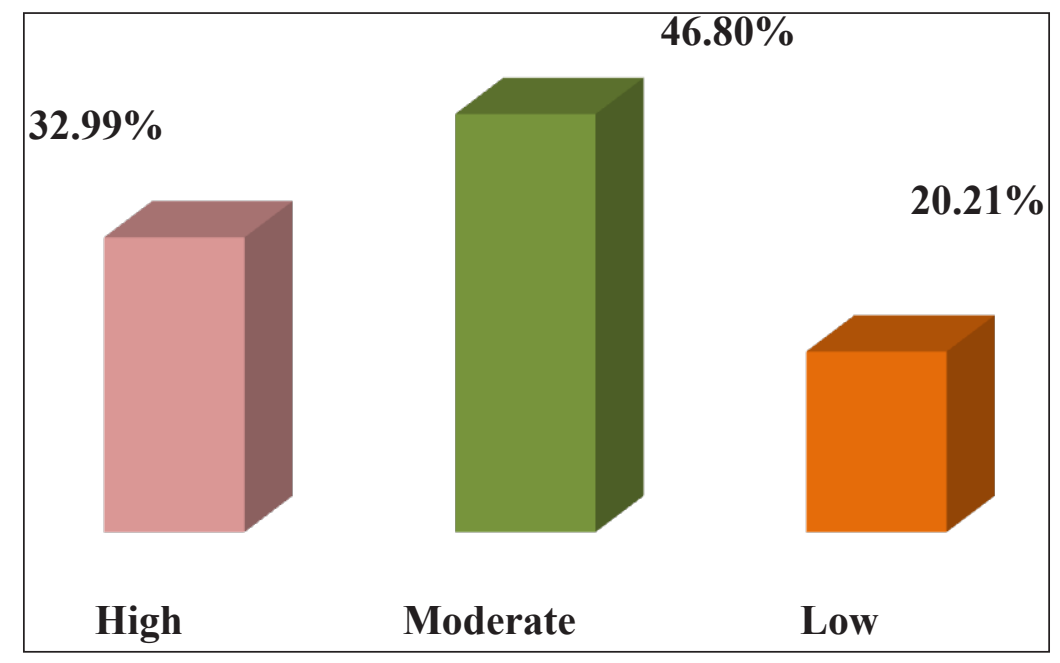

Fig. 7: Overall satisfaction with the use of MOOCs

\section{FINDINGS,CONCLUSION AND RECOMMENDATIONS}

This study is conducted to explore the various perspectives of MOOCs adoption by the engineering faculties of Karnataka state. Their adoption, perceived benefits from adoption, barriers in adoption and also the overall satisfaction with the adoption are assessed. The study found the under use of MOOCs platforms by the engineering faculties even though most of them are very familiar with various MOOCs platforms. It is no doubt that the adoption 
of MOOCs has helped the faculties in many ways like gaining knowledge and conducting research. The perceived benefits further corroborate that the adoption has aided the faculties in developing their carrier. Even though some challenges are being faced by the cohorts like lack of time and interest which should be addressed. Overall, our study reported that most of the participants are moderately satisfied with the adoption of MOOCs.

ICT can be a powerful tool for transforming teaching and learning as stated by (Trust, 2018). The need for implementing technologies into academia has become the need of the hour as the student's preference for electronic/digital class approach. It is suggested the faculties be updated with technologies and recommended to implement the same for effective teaching and learning. Fennell (2018) opined that, from knowing the syllabus contents in the books, faculties need to have the industry experience to bring the real-world experience to the lecture hall. Higher the use of technology means higher the degree of collaboration. The technology alone does nothing to enhance pedagogy/andragogy which means that faculty must be trained in the use of the tools-not just given access to the tools (Jackson, 2011). The world is moving towards digital and the same with the case with India too in the form of imparting teaching and learning through MOOCs. It is the need of the hour to better never late to start more adoption of MOOCs in teaching and learning activities.

\section{RECOMMENDATIONS}

1. Awareness should be given to faculties about various MOOCs platforms especially Indian initiation like SWAYAM.

2. The concerned institutions should offer all the facilities to the faculties to develop and integrate MOOCs.

3. Training can be impacted by faculties to increase digital literacy skills.

4. MOOCs providers should be taken into account the interests of faculties and students while making MOOCs courses.

\section{REFERENCES}

Amantha Kumar, J. and Al-Samarraie, H. 2019. An Investigation of Novice Pre-University Students' Views towards MOOCs: The Case of Malaysia. Reference Librarian, 60(2): 134-147.

Arya, U. 2017. The rise of MOOCs (Massive Open Online Courses) and other similar online courses variants -analysis of textual incidences in cyberspace. Journal of Content, Community and Communication, 6(2015): 26-35.

Bakogianni Eleni, M., Tsitouridou and Kyridis, A. 2020. MOOCs in teachers' professional development: examining teacher readiness.

Barnes, C. 2013. MOOCs: The Challenges for Academic Librarians. Australian Academic and Research Libraries, 44(3): 163-175.

Barriers, U. and Mooc, O.F. 2018. Understanding the barriers of MOOCs adoption, pp. 1-32. 
XP Vysakh and Rajendra

Brahimi, T. and Sarirete, A. 2015. Learning outside the classroom through MOOCs. Computers in Human Behavior, 51: 604-609.

Brian, R. 2019. The Best MOOC Platforms. Retrieved from Reviews.Com website: https://www.reviews.com/ mooc-platforms/

Chakravarty, R. and Kaur, J. 2016. MOOCs in India: Yet to Shine. International Journal of Information Studies and Libraries, $\mathbf{1}(1)$.

Chatterjee, P. and Asoke, N. 2014. Massive Open Online Courses ( MOOCs ) in Education - A Case Study in Indian Context and Vision to Ubiquitous Learning. (December). https://doi.org/10.1109/MITE.2014.7020237

Dhawal, S. 2018. By The Numbers: MOOCs in 2018. Retrieved December 5, 2019, from https://www.classcentral. com/report/mooc-stats-2018/

Fennell, B. 2018. Professional and Technical Qualifications for Engineering Faculty: An Important Decision. Journal of Professional Issues in Engineering Education and Practice, 144(1): 1-2.

Goel, S. 2007. Women in Engineering in India. The International Journal of Interdisciplinary Social Sciences: Annual Review, 1(6): 49-56.

Jackson, L.D. 2011. From novice to tech savvy teachers. Ricerche Di Pedagogia e Didattica, 6(1): 1-19.

Kay, J., Reimann, P., Diebold, E. and Kummerfeld, B. 2013. MOOCs: So Many Learners, So Much Potential What Is a MOOC? AI and Education, 2-9. Retrieved from https://pdfs.semanticscholar. org/9e3f/56c7e2a816fb44d8fd1bd2a2441eb6dde83e.pdf

Khalil, A. and Sultana, N. 2017. Reshaping Teachers ' e-Training through MOOCs in Pakistan. NICE Research Journal, (June), pp. 13-28.

Margaryan, A., Bianco, M. and Littlejohn, A. 2015. Instructional quality of Massive Open Online Courses (MOOCs). Computers and Education, 80: 77-83.

Mohan, M.M., Upadhyaya, P. and Pillai, K.R. 2020. Intention and barriers to use MOOCs: An investigation among the postgraduate students in India. Education and Information Technologies, (Chauhan 2017). https:// doi.org/10.1007/s10639-020-10215-2

Muhammad, S.H., Mustapha, B.A. and Haruna, K. 2016. Open Online Courses: Awareness, Adoption, Benefits and Challenges in Sub-Saharan Africa. International Journal of ICT and Management A, 4(2): 60-68.

Nagasampige, M., Subbaiah, G.D. and Nagasampige, K. 2020. MOOCs in Indian University Education System: A study on awareness and motivation among students and teachers of Indian Universities. Retrieved from http:// www.scdl.net/InternationalConference/PDFS/DigitalProceeding/T-Dr manojkumar nagasampege Gayatri Devi Full Paper.pdf

Natalie, M. 2018. MOOC users reach 58 million globally. Retrieved December 5, 2019, from The Pie News website: https://thepienews.com/news/edu-tech/mooc-users-reach-58-million-globally/

Pradeep Kumar, M. 2018. MOOCs for Teacher Professional Development: Reflections, and Suggested Actions. Open Praxix, 10(1): 67-77.

Sawant, S. 2016. MOOCs as a means of continuing professional development for LIS educators in India.

Schrum, L., Shelley, G.L. and Miller, R. 2008. Understanding Tech-Savvy Teachers: Identifying Their Characteristics, Motivation, and Challenges. International Journal of Technology in Teaching and Learning, 4(1): 1.

Shaikh, S.A. 2017. Student-teacher awareness of MOOCs - massive. International Journal of Educational Science and Research (IJESR), 7(6): 105-110. 
MOOCs: Adoption, Perceived Benefits and Hurdles among the Engineering Faculties of Karnataka Y P

Singh, G. and Chauhan, R. 2017. Awareness towards Massive Open Online Courses (MOOCs) and their usage for Teacher Education in India. Asian Journal of Distance Education, 12(2): 81-88.

Soyemi, O.D. and Babalola, Y.T. 2018. Awareness and Use of Massive Open Online Courses among Academic Librarians in Ogun state, Nigeria. Journal of Information and Knowledge Management, 9(1): 1-11.

Trust, T. 2018. Why Do We Need Technology in Education? Journal of Digital Learning in Teacher Education, 34(2): 54-55.

Yuan, L. and Stephen, P. 2018. MOOCs and Open Education. JISC Cetis. https://doi.org/10.4324/9781315751108-1 
